\title{
A Miocene pygmy right whale fossil from Australia
}

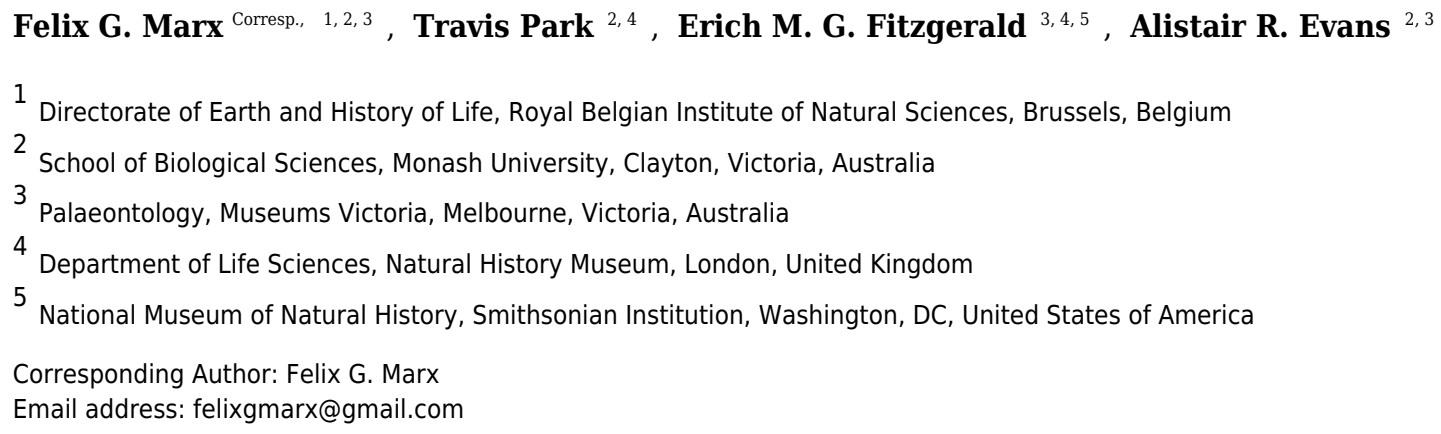

Neobalaenines are an enigmatic group of baleen whales represented today by a single living species: the pygmy right whale, Caperea marginata, found only in the Southern Hemisphere. Molecular divergence estimates date the origin of pygmy right whales to 22-26 Ma, yet to date there are only three confirmed fossil occurrences. Here, we describe an isolated periotic from the latest Miocene of Victoria (Australia). The new fossil shows all the hallmarks of Caperea, making it the second-oldest described neobalaenine, and the oldest record of the genus. Overall, the new specimen resembles Caperea marginata in its external morphology and details of the cochlea, but is more archaic in it having a hypertrophied suprameatal area and a greater number of cochlear turns. The presence of Caperea in Australian waters during the Late Miocene matches the distribution of the living species, and supports a southern origin for pygmy right whales. 


\section{A Miocene pygmy right whale fossil from Australia}

2 Felix G. Marx ${ }^{1-3}$, Travis Park ${ }^{2,4}$, Erich M.G. Fitzgerald ${ }^{3-5}$ and Alistair R. Evans ${ }^{2,3}$

$3{ }^{1}$ Directorate of Earth and History of Life, Royal Belgian Institute of Natural Sciences, Brussels, Belgium.

$4 \quad{ }^{2}$ School of Biological Sciences, Monash University, Clayton, Victoria, Australia.

5 3Palaeontology, Museums Victoria, Melbourne, Australia.

$6 \quad{ }^{4}$ Department of Life Sciences, Natural History Museum, London, UK.

$7 \quad{ }^{5}$ National Museum of Natural History, Smithsonian Institution, Washington, DC, USA.

8 Correspondence to: felix.marx@monash.edu

Abstract: Neobalaenines are an enigmatic group of baleen whales represented today by a single living species: the pygmy right whale, Caperea marginata, found only in the Southern Hemisphere. Molecular divergence estimates date the origin of pygmy right whales to 22-26 Ma, yet to date there are only three unambiguous fossil occurrences. Here, we describe an isolated periotic from the latest Miocene of Victoria (Australia). The new fossil shows all the hallmarks of Caperea, making it the second-oldest described neobalaenine, and the oldest record of the genus. Overall, the new specimen resembles Caperea marginata in its external morphology and details of the cochlea, but is more archaic in it having a hypertrophied suprameatal area and a greater number of cochlear turns. The presence of Caperea in Australian waters during the Late Miocene matches the distribution of the living species, and supports a southern origin for pygmy right whales.

\section{INTRODUCTION}

The living pygmy right whale, Caperea marginata (Gray 1846), is the smallest living baleen whale, and the only living representative of its lineage (Neobalaeninae). Its ecology and 
structure (Beddard 1901; Buchholtz 2011), visual capabilities (Meredith et al. 2013), and even the evolution of its mitochondrial tRNAs (Montelli et al. 2016).

The evolution of pygmy right whales is equally obscure, with their phylogenetic position being controversial (Bisconti 2015; Boessenecker \& Fordyce 2015; El Adli et al. 2014; Fordyce \& Marx 2013; Gol'din \& Steeman 2015; Marx \& Fordyce 2016; McGowen et al. 2009), and their fossil record being all but non-existent. Even though molecular divergence estimates date the origin of neobalaenines to 26-22 Ma (McGowen et al. 2009; Steeman et al. 2009), fossils are currently limited to just Miocaperea pulchra Bisconti, 2012 from the Late Miocene of Peru, and two Pleistocene Caperea-like specimens from the Northern Hemisphere (Tsai et al. 2017). Additional Late Miocene material from Argentina (Buono et al. 2014) and Australia (Fitzgerald 2012) is fragmentary, and uncertainly identified. Cetotheriids are closely related to neobalaenines, and generally more abundant; yet, based on the age of Miocaperea, pygmy right whales diverged from other cetotheriids at least prior to $8 \mathrm{Ma}$, and probably considerably earlier.

The global dearth of pygmy right whale fossils is striking, and suggests that neobalaenines have either been overlooked or, throughout their evolution, have been rare and/or geographically restricted. Here, we report a new fossil of Caperea from the latest Miocene of southern Australia - the second oldest confirmed neobalaenine, and the oldest record of the genus - and discuss its implications for the evolution and biogeography of the lineage as a whole.

\section{MATERIAL AND METHODS}

\section{Collection and photography}

The specimen was collected in the first half of the 20th century by G. B. Pritchard, and subsequently formed part of the stratigraphic reference collection at Museums Victoria, Melbourne, until it was identified by FGM and EMGF in 2017. Morphological terminology follows Mead \& Fordyce (2009), unless indicated. For the figures, photographs of the specimen were digitally focus stacked in Photoshop CS6.

\section{Scanning technique}


54 The periotic was scanned using the Zeiss Xradia 520 Versa at the Monash University X-ray

55 Microscopy Facility for Imaging Geo-materials (XMFIG) The raw CT data were compiled into a

$563 \mathrm{D}$ model, and digital endocasts of the cochlea segmented using the visualisation software

57 package Avizo (Version 9.2.0 Standard) (FEI). 3D models of both the periotic and the inner ear

58 are available as Supplementary Material.

59 Cochlear measurements

60 Basic measurements of the internal structures of the cochlea were taken using the Measure, Slice 61 and Spline Probe tools in Avizo, following the protocols of Park et al. (2016), and subsequently

62 used to calculate standard ratios (axial pitch and cochlear slope) used to quantify cochlear shape

63 (Ketten \& Wartzok 1990). The radii ratio (and thus also the low frequency hearing limit) could

64 not be calculated, as damage prevented us from obtaining a basal radius. See Park et al. (2017b)

65 for a detailed description of all measurements and procedures.

66

67

68

69

70

71

72

73

74

75

76

77

78

79

Institutional abbreviations

NMV, Museums Victoria, Melbourne.

8

RESULTS

Systematic palaeontology

1 Cetacea Brisson, 1762

72 Mysticeti Gray, 1864

73 Cetotheriidae Brandt, 1872

74 Neobalaeninae Gray, 1873

75 Caperea Gray 1864

6 Caperea sp.

77 Figures 1-4

Referred material. NMV P233333, partial right periotic preserving the pars cochlearis, body of the periotic, and suprameatal area.

Locality and horizon. Beaumaris Bay, northeast side of Port Phillip Bay, Victoria, southeast Australia, near $37^{\circ} 59^{\prime} 34^{\prime} \mathrm{S}, 145^{\circ} 02^{\prime} 32^{\prime \prime} \mathrm{E}$. At Beaumaris, the basal phosphatic nodule bed and 
82 overlying $\sim 7$ metres of the shallow marine Sandringham Sandstone (VandenBerg 2016) produce

83 a rich, albeit largely unpublished, assemblage of marine and rare terrestrial vertebrates (see

84 Fitzgerald \& Kool 2015, and references therein). Although NMV P233333 was originally

85 collected as float, its polished surfaces suggest that it was derived from the phosphatic nodule

86 bed at the base of the Sandringham Sandstone. ${ }^{87} \mathrm{Sr} /{ }^{86} \mathrm{Sr}$ ratios from phosphatic intraclasts within

87 the latter horizon yield dates ranging from 6.24-5.38 Ma, with dates of 5.98 and 5.59 Ma within

881 metre above the phosphatic nodule bed (Dickinson \& Wallace 2009). These data suggest that

89 NMV P233333 is latest Miocene (Messinian) in age, between 6.2 and 5.4 Ma.

Description

External anatomy. The new specimen from Australia preserves much of the pars cochlearis, except for its anteromedial corner (Figs 1 and 2). The surface is abraded, but fractured areas are generally flattened and delimited by a clearly defined rim. The anterior and compound posterior processes are lost, but breakage indicates the shape and size of their respective attachments. Notably, the base of the anterior process is small, suggesting that it was separated from the body of the periotic by a marked constriction.

In medial view (Figs 1A and 2A), the pars cochlearis is longer (ca $29 \mathrm{~mm}$ ) than high, with no signs of elongation along its preserved cranial rim. The medial surface is eroded, making it impossible to tell whether a promontorial groove was present. The suprameatal area specifically, the pyramidal process - is hypertrophied, and forms a broadly triangular protuberance that rises dorsally well above the level of the pars cochlearis. Medially, this protuberance is excavated by a sulcus originating from the dorsal vestibular area.

The mallear fossa is either poorly defined or, probably, worn away. The fenestra cochleae is slightly recessed into the posterior face of the pars cochlearis, but remains clearly visible. The posterior cochlear crest (see Ekdale et al. (2011) for a discussion of this term) is small and effectively absent. Abrasion likely somewhat reduced its length, but - judging from the generally good state of preservation in this area - not to a major degree. Posteromedial to the fenestra cochleae, the pars cochlearis somewhat bulges posteriorly, further precluding the presence of a large posterior cochlear crest. 
111 In ventral view (Figs 1B and 2B), the fenestra vestibuli is large (ca $6.5 \mathrm{~mm}$ ) and slightly oval.

112 There is no distal opening of the facial canal; instead, the latter is entirely open, and developed as

113 a sulcus running lateral to the fenestra vestibuli and on to the anterior face of the pars cochlearis.

114 Medially and laterally, the distal portion of the canal is sheltered by the pars cochlearis and the

115 base of the anterior process, respectively, suggesting that the lack of a bony floor is genuine and

116 not simply a result of abrasion. The fossa for the stapedial muscle is small, and notably offset

117 from the facial sulcus.

118 In dorsal view (Figs $1 \mathrm{C}$ and 2C), the dorsal vestibular area is rounded, ca $5.5 \mathrm{~mm}$ in diameter, 119 and approximately aligned with the proximal portion of the facial canal and the aperture for the 120 cochlear aqueduct. The crista transversa is robust and widely separates the dorsal vestibular area

121 from the facial canal. The aperture for the cochlear aqueduct is approximately circular (max.

122 diameter $2.5 \mathrm{~mm}$ ), and located medial to the level of the aperture for the vestibular aqueduct.

123 There is no anteroposterior overlap of the two apertures, and thus no en echelon arrangement as

124 seen in balaenopteroids (Ekdale et al. 2011). The aperture for the vestibular aqueduct is

125 developed as a broad slit (max. diameter $8 \mathrm{~mm}$ ).

126 In anterior view (Figs 1D and 2D), the facial canal extends to the cranial rim of the pars

127 cochlearis. It is unclear whether the canal was entirely exposed in life, or whether its proximal

128 portion was once floored, as seen in Caperea marginata. Lateral to the facial sulcus, and anterior

129 to the suprameatal area, there is a small area of spongy bone, as seen in C. marginata and a

130 variety of other chaeomysticetes. In posterior view (Figs 1E and 2E), the fenestra cochleae is

131 large (ca $9 \mathrm{~mm}$ ), oval, and somewhat oblique relative to the dorsoventral axis of the pars

132 cochlearis. The fenestra cochleae and aperture of the cochlear aqueduct are well separated.

133 Inner ear. The basalmost quarter turn of the cochlea was partially damaged, but enough

134 remained to enable its reconstruction (Fig. 3). The cochlea completes 2.5 turns and bears a

135 distinct tympanal recess, with the scala tympani being inflated radially along approximately the

136 first half turn of the cochlear canal. In vestibular view, the apical turn is tightly coiled and

137 encloses a small open space. The entire apical turn overlaps the section of the cochlear canal

138 immediately below. The reconstructed portion of the cochlea has a height of $12.89 \mathrm{~mm}$, a width

139 of $16.33 \mathrm{~mm}$, a volume of $856.63 \mathrm{~mm}^{3}$, and a canal length of $52.37 \mathrm{~mm}$; inside the basal turn, the 
140 secondary spiral lamina extends for $15.71 \mathrm{~mm}$, equal to approximately $30 \%$ of the total length of

141 the cochlear canal. The basal ratio is 0.79 , the axial pitch 5.16, and the cochlear slope 0.10 .

142

143

144

145

146

147

148

149

150

151

152

153

154

155

156

157

158

159

160

161

162

163

164

165

166

167

\section{DISCUSSION AND CONCLUSIONS}

\section{Comparisons}

NMV P233333 closely resembles extant Caperea marginata, but not Miocaperea (Bisconti 2012), in having a (partially) open facial canal, a nearly absent posterior cochlear crest, and a distinct neck separating the anterior process from the body of the periotic (Fig. 4). In addition, both share the presence of relatively large fenestrae cochleae and vestibuli; the oblique orientation of the fenestra cochleae; the well-developed pyramidal process; and the retention of a small, circular aperture for the cochlear aqueduct that is well separated from the aperture for vestibular aqueduct (Fig. 5).

The open facial sulcus and constricted base of the anterior process are unique to Caperea, and strongly suggest referral of NMV P23333 to this genus. The new specimen differs from $C$. marginata, however, in having a markedly wider crista transversa, a larger pyramidal process, a larger stylomastoid fossa, and a more robust neck of anterior process. The combination of these features may suggest the existence of a separate, more archaic species of Caperea, but the fragmentary nature of the specimen prevents us from drawing firmer conclusions. Notably, a similarly robust pyramidal process also occurs in several cetotheriids, including Kurdalagonus, Mithridatocetus, and Herpetocetus.

A tympanal recess of the cochlea is typical of Caperea and most other plicogulans, but not balaenids and more archaic mysticetes, such as eomysticetids (Park et al. 2017b). Two and a half turns give the cochlea a more archaic aspect than that of $C$. marginata, and are broadly in line with the number of turns in most other mysticetes (Ekdale 2016; Ritsche et al. 2018). The height and volume of the cochlea are larger than in most mysticetes, but similar to that of C. marginata. The axial pitch is also most similar to Caperea, whereas the cochlear slope value is higher than in all other mysticetes (Ekdale 2016; Park et al. 2017a; Park et al. 2017b), and more similar to that of Zygorhiza or even some odontocetes (Park et al. 2016). 


\section{Origins of Caperea}

169 Extant Caperea is restricted to the Southern Hemisphere, which, until recently, had also been the 170 sole source of neobalaenine fossils (Bisconti 2012; Buono et al. 2014; Fitzgerald 2012). The 171 recent description of two Pleistocene Caperea-like fossils from Italy and Japan provided the first 172 evidence that pygmy right whales once crossed the equator, likely during brief glacial intervals 173 associated with Northern Hemisphere glaciation (Tsai et al. 2017).

174 The idea that neobalaenines originated in the Southern Hemisphere and only briefly ventured 175 north is plausible, but so far has remained difficult to test in light of the sparse fossil record. 176 Thus, until now, the two northern occurrences of Caperea constituted the majority of the 177 confidently identified neobalaenine record, contrasted only by Miocaperea pulchra from the Late 178 Miocene of Peru. Our new specimen firms up the ancient southern history of the Caperea 179 lineage, and suggests that neobalaenines may indeed have originated in austral seas (Fig. 6).

180

181

182

183

184

185

186

187

188

189

190

191

192

193

194

195 196

Additionally, our identification of an unambiguous neobalaenine periotic from the Sandringham Sandstone at Beaumaris corroborates Fitzgerald's (2012) account of an isolated, putatively neobalaenine compound posterior process from the same unit and locality. Unlike our new material, the specimen described by Fitzgerald (2012) is notably larger than adult Caperea marginata, raising the possibility that it represents a distinct taxon. On the other hand, the posterior process of mysticetes dramatically increases in both absolute and relative size during ontogeny (Bisconti 2001), making it plausible that the two Beaumaris specimens may be congeneric or even conspecific.

Historically, Miocene and Pliocene assemblages from the Northern Hemisphere have been investigated more intensively than those from the south (Boessenecker 2013; Brandt 1873; Gol'din \& Startsev 2016; Gottfried et al. 1994; Hampe \& Ritsche 2011; Kohno et al. 2007; Oishi \& Hasegawa 1995a; Steeman 2010; Van Beneden 1882; Van Beneden 1886; Whitmore \& Kaltenbach 2008), presumably because of the greater number of local researchers. Yet, despite these efforts, northern neobalaenines have remained elusive, including from the highly fossiliferous assemblages of Belgium (Steeman 2010), northern Italy (Bisconti 2009), Japan (Oishi \& Hasegawa 1995a; Oishi \& Hasegawa 1995b), and both the eastern and western coasts of the United States (Boessenecker 2013; Gottfried et al. 1994; Whitmore \& Kaltenbach 2008). 
197 By contrast, comparatively limited work in the Southern Hemisphere has yielded specimens

198 from Australia (Fitzgerald 2012; this study), Peru (Bisconti 2012) and, possibly, Argentina

199 (Buono et al. 2014), ranging in age from 10-5 Ma.

200 Given the marked discrepancy, we suggest that the absence of Caperea in the Northern

201 Hemisphere during the Miocene and Pliocene is a genuine phenomenon. Fossil neobalaenines

202 remain rare in the north since they mostly, or perhaps exclusively, occurred there during the

203 Pleistocene (Tsai et al. 2017). Sea levels at that time were markedly lower than today (Miller et

204 al. 2005), leading to coeval marine deposits becoming eroded and/or inundated whenever the ice

205 retreated. In the south, the rarity of neobalaenine fossils may reflect genuine biological scarcity

206 or habitat restriction, but likely also a simple lack of research effort. We predict that, as more

207 Miocene and Pliocene assemblages are studied, neobalaenines will continue to emerge primarily

208 from southern field sites and collections.

\section{ACKNOWLEDGEMENTS}

211

212

213

214

215

216

217

218

219

220

221

222

223

224

225

226

227

We thank David P. Hocking for assistance with scanning, Tim Ziegler for access to specimens, Carl Buell for providing illustrations of extant whales, and Cheng-Hsiu Tsai, Robert W.

Boessenecker and an anonymous reviewer for their constructive comments.

\section{REFERENCES}

Beddard FE. 1901. Contribution towards a knowledge of the osteology of the pigmy whale (Neobalaena marginata). Transactions of the Zoological Society of London 16:87-115.

Bisconti M. 2001. Morphology and postnatal growth trajectory of rorqual petrosal. Italian Journal of Zoology 68:87-93.

Bisconti M. 2009. Taxonomy and evolution of the Italian Pliocene Mysticeti (Mammalia, Cetacea): a state of the art. Bollettino della Societa Paleontologica Italiana 48:147-156.

Bisconti M. 2012. Comparative osteology and phylogenetic relationships of Miocaperea pulchra, the first fossil pygmy right whale genus and species (Cetacea, Mysticeti, Neobalaenidae). Zoological Journal of the Linnean Society 166:876-911. 10.1111/j.10963642.2012.00862.x

Bisconti M. 2015. Anatomy of a new cetotheriid genus and species from the Miocene of Herentals, Belgium, and the phylogenetic and palaeobiogeographical relationships of 
Cetotheriidae s.s. (Mammalia, Cetacea, Mysticeti). Journal of Systematic Palaeontology 13:377-395. 10.1080/14772019.2014.890136

Boessenecker RW. 2013. A new marine vertebrate assemblage from the Late Neogene Purisima Formation in Central California, part II: Pinnipeds and Cetaceans. Geodiversitas 35:815940.

Boessenecker RW, and Fordyce RE. 2015. A new genus and species of eomysticetid (Cetacea: Mysticeti) and a reinterpretation of 'Mauicetus' lophocephalus Marples, 1956: transitional baleen whales from the upper Oligocene of New Zealand. Zoological Journal of the Linnean Society 175:607-660. 10.1111/zoj.12297

Brandt JF. 1872. Über eine neue Classification der Bartenwale (Balaenoidea) mit berücksichtigung der untergegangenen Gattungen derselben. Bulletin de l'Académie impériale des Sciences de Saint Pétersbourg 17:113-124.

Brandt JF. 1873. Untersuchungen über die fossilen und subfossilen Cetaceen Europa's. Mémoires de l'Académie impériale des sciences de St-Pétersbourg 20:1-371.

10.5962/bhl.title.39524

Brisson MJ. 1762. Regnum animale in classes IX distributum, sive synopsis methodica sistens generalem animalium distributionem in classes $I X$, \& duarum primarum classium, quadripedum scilicet \& cetaceorum, particularum divisionem in ordines, sectiones, genera, \& species. Ed. 2. Leiden: Theodorum Haak, Lugduni Batavorum.

Buchholtz EA. 2011. Vertebral and rib anatomy in Caperea marginata: implications for evolutionary patterning of the mammalian vertebral column. Marine Mammal Science 27:382-397. 10.1111/j.1748-7692.2010.00411.x

Buono MR, Dozo MT, Marx FG, and Fordyce RE. 2014. A Late Miocene potential neobalaenine mandible from Argentina sheds light on the origins of the living pygmy right whale. Acta Palaeontologica Polonica 59:787-793.

Dickinson JA, and Wallace MW. 2009. Phosphate-rich deposits associated with the MioPliocene unconformity in south-east Australia. Sedimentology 56:547-565. 10.1111/j.1365-3091.2008.00985.x

Ekdale EG, Berta A, and Demere TA. 2011. The comparative osteology of the petrotympanic complex (ear region) of extant baleen whales (Cetacea: Mysticeti). PLOS ONE 6:e21311. e2131110.1371/journal.pone.0021311

Ekdale EG. 2016. Morphological variation among the inner ears of extinct and extant baleen whales (Cetacea: Mysticeti). Journal of Morphology:published online. 10.1002/jmor.20610

El Adli JJ, Deméré TA, and Boessenecker RW. 2014. Herpetocetus morrowi (Cetacea: Mysticeti), a new species of diminutive baleen whale from the Upper Pliocene (Piacenzian) of California, USA, with observations on the evolution and relationships of the Cetotheriidae. Zoological Journal of the Linnean Society 170:400-466. 10.1111/zoj.12108

Fitzgerald EMG. 2012. Possible neobalaenid from the Miocene of Australia implies a long evolutionary history for the pygmy right whale Caperea marginata (Cetacea, Mysticeti). Journal of Vertebrate Paleontology 32:976-980.

Fitzgerald EMG, and Kool L. 2015. The first fossil sea turtles (Testudines: Cheloniidae) from the Cenozoic of Australia. Alcheringa: An Australasian Journal of Palaeontology 39:142148. $10.1080 / 03115518.2015 .964047$ 
273

274

275

276

277

278

279

280

281

282

283

284

285

286

287

288

289

290

291

292

293

294

295

296

297

298

299

300

301

302

303

304

305

306

307

308

309

310

311

312

313

314

315

316

317

318

Fordyce RE, and Marx FG. 2013. The pygmy right whale Caperea marginata: the last of the cetotheres. Proceedings of the Royal Society B 280:20122645. 10.1098/rspb.2012.2645

Gol'din P, and Steeman ME. 2015. From problem taxa to problem solver: a new Miocene family, Tranatocetidae, brings perspective on baleen whale evolution. PLOS ONE 10:e0135500. 10.1371/journal.pone.0135500

Gol'din P, and Startsev D. 2016. A systematic review of cetothere baleen whales (Cetacea, Cetotheriidae) from the Late Miocene of Crimea and Caucasus, with a new genus. Papers in Palaeontology:published online. 10.1002/spp2.1066

Gottfried MD, Bohaska DJ, and Whitmore FC. 1994. Miocene cetaceans of the Chesapeake Group. Proceedings of the San Diego Society of Natural History 29:229-238.

Gray JE. 1846. On the cetaceous animals. In: Richardson J, and Gray JE, eds. The zoology of the voyage of H M S Erebus and Terror under the command of Captain Sir James Clark Ross, R N, FR S, during the years 1839 to 1843 Volume 1 Mammalia, Birds. London: E. W. Janson, 13-53.

Gray JE. 1864. XXXVIII. Notes on the whalebone-whales; with a synopsis of the species. Annals And Magazine of Natural History 14:345-353.

Gray JE. 1873. Remarks on some of the species in the foregoing paper (in: Notes on the whales and dolphins of the New-Zealand seas. With remarks by Dr. J. E. Gray F. R. S. \&c.). Annals And Magazine of Natural History 11:107-112.

Hampe O, and Ritsche I. 2011. Die Bartenwalfauna (Cetacea: Mysticeti: Balaenomorpha) aus dem Lüneburgium (Serravallium, Mittelmiozän) von Freetz bei Sittensen (Niedersachsen, Deutschland) Zeitschrift für Geologische Wissenschaften 39:83-110.

Ketten DR, and Wartzok D. 1990. Three-dimensional reconstructions of the dolphin ear. NATO ASI (Advanced Science Institutes) Series Series A Life Sciences 196:81-105.

Kohno N, Koike H, and Narita K. 2007. Outline of fossil marine mammals from the Middle Miocene Bessho and Aoki Formations, Nagano Prefecture, Japan. Research Report of the Shinshushinmachi Fossil Museum 10:1-45.

Marx FG, and Fordyce RE. 2016. A link no longer missing: new evidence for the cetotheriid affinities of Caperea. PLOS ONE 11:e0164059. 10.1371/journal.pone.0164059

McGowen MR, Spaulding M, and Gatesy J. 2009. Divergence date estimation and a comprehensive molecular tree of extant cetaceans. Molecular Phylogenetics and Evolution 53:891-906. 10.1016/j.ympev.2009.08.018

Meredith RW, Gatesy J, Emerling CA, York VM, and Springer MS. 2013. Rod monochromacy and the coevolution of cetacean retinal opsins. PLOS Genetics 9:e1003432. 10.1371/journal.pgen.1003432

Miller KG, Kominz MA, Browning JV, Wright JD, Mountain GS, Katz ME, Sugarman PJ, Cramer BS, Christie-Blick N, and Pekar SF. 2005. The Phanerozoic record of global sealevel change. Science 310:1293-1298. 10.1126/science.1116412

Montelli S, Peruffo A, Patarnello T, Cozzi B, and Negrisolo E. 2016. Back to water: signature of adaptive evolution in cetacean mitochondrial tRNAs. PLOS ONE 11:e0158129. 10.1371/journal.pone.0158129

Oishi M, and Hasegawa Y. 1995a. A list of fossil cetaceans in Japan. The Island Arc 3:493-505.

Oishi M, and Hasegawa Y. 1995b. Diversity of Pliocene mysticetes from eastern Japan. Island Arc 3:436-452. 10.1111/j.1440-1738.1994.tb00124.x

Park T, Fitzgerald EMG, and Evans AR. 2016. Ultrasonic hearing and echolocation in the earliest toothed whales. Biology Letters 12:20160060. 10.1098/rsb1.2016.0060 
319

320

321

322

323

324

325

326

327

328

329

330

331

332

333

334

335

336

337

338

339

340

341

342

343

344

345

346

347

348

349

350

351

352

353

354

355

356

Park T, Evans AR, Gallagher SJ, and Fitzgerald EMG. 2017a. Low-frequency hearing preceded the evolution of giant body size and filter feeding in baleen whales. Proceedings of the Royal Society B 284:20162528. 10.1098/rspb.2016.2528

Park T, Marx FG, Fitzgerald EMG, and Evans AR. 2017b. The cochlea of the enigmatic pygmy right whale Caperea marginata informs mysticete phylogeny. Journal of Morphology 278:801-809. 10.1002/jmor.20674

Ritsche IS, Fahlke JM, Wieder F, Hilger A, Manke I, and Hampe O. 2018. Relationships of cochlear coiling shape and hearing frequencies in cetaceans, and the occurrence of infrasonic hearing in Miocene Mysticeti. Fossil Record 21:33-45. 10.5194/fr-21-33-2018

Steeman ME, Hebsgaard MB, Fordyce RE, Ho SYW, Rabosky DL, Nielsen R, Rahbek C, Glenner H, Sorensen MV, and Willerslev E. 2009. Radiation of extant cetaceans driven by restructuring of the oceans. Systematic Biology 58:573-585. 10.1093/sysbio/syp060

Steeman ME. 2010. The extinct baleen whale fauna from the Miocene-Pliocene of Belgium and the diagnostic cetacean ear bones. Journal of Systematic Palaeontology 8:63-80. 10.1080/14772011003594961

Tsai C-H, Collareta A, Fitzgerald EMG, Marx FG, Kohno N, Bosselaers M, Insacco G, Reitano A, Catanzariti R, Oishi M, and Bianucci G. 2017. Northern pygmy right whales highlight Quaternary marine mammal interchange. Current Biology 27:R1058-R1059. 10.1016/j.cub.2017.08.056

Van Beneden P-J. 1882. Description des ossements fossiles des environs d'Anvers. Troisième partie. Cétacés. Genres Megaptera, Balaenoptera, Burtinopsis et Erpetocetus. Annales du Musée Royal d'Histoire Naturelle de Belgique 7:1-87.

Van Beneden P-J. 1886. Description des ossements fossiles des environs d'Anvers. Cinquième partie. Cétacés. Genres Amphicetus, Heterocetus, Mesocetus, Idiocetus et Isocetus. Annales du Musée Royal d'Histoire Naturelle de Belgique 13:1-139.

VandenBerg AHM. 2016. Depositonal facies and extent of the late Neogene Sandringham Sandstone in southern Victoria, Australia. Proceedings of the Royal Society of Victoria 128:7-24. 10.1071/RS16009

Whitmore FC, Jr., and Kaltenbach JA. 2008. Neogene Cetacea of the Lee Creek Phosphate Mine, North Carolina. Virginia Museum of Natural History Special Publication 14:181-269.

\section{Figure captions}

Figure 1. Caperea sp. (NMV P233333), right periotic - photographs. (A) medial, (B) ventral, (C) dorsal, (D) anterior and (E) posterior view. Photo credit: Felix G. Marx.

Figure 2. Caperea sp. (NMV P233333), right periotic - explanatory line drawings. Photo credit: Felix G. Marx.

Figure 3. Inner ear of Caperea sp. (NMV P233333). Digital model reconstructed from microCT data in (A) anterior, (B) lateral, (C) dorsal and (D) vestibular view. 
357 Figure 4. Comparison of Caperea sp. with extant $\boldsymbol{C}$. marginata. (A, D) Caperea sp. (NMV

358 P233333) and (B, C) extant C. marginata (NMV C28531) in (A, B) ventral and (C, D) posterior 359 view. Photo credit: Felix G. Marx.

360 Figure 5. Comparison of Caperea sp. with extant C. marginata. (A) Caperea marginata

361 (NMV C28531) and (B) Caperea sp. (NMV P233333), both in dorsal view. Photo credit: Felix

362 G. Marx.

363 Figure 6. Global occurrence and age of neobalaenine fossils. (A) Map illustrating

364 neobalaenine fossil localities, as well as the geographical distribution of extant Caperea

365 marginata. (B) Simplified phylogeny showing the fossil record of the three major lineages of

366 extant baleen whales. For neobalaenines, dark green and red denote Southern and Northern

367 Hemisphere occurrences, respectively. Grey illustrates the total cetotheriid fossil record. The age

368 of NMV P233333 is marked with an asterisk. (A) modified from Tsai et al. (2017), (B) from

369 Fitzgerald (2012) and Buono et al. (2014), under a Creative Commons Attribution License.

370 Drawings of extant whales by Carl Buell. L., Late; Pleist., Pleistocene; Plio., Pliocene; Qu.,

371 Quaternary. 


\section{Figure 1}

Caperea sp. (NMV P233333), right periotic - photographs.

(A) medial, (B) ventral, (C) dorsal, (D) anterior and (E) posterior view. Photo credit: Felix G. Marx. 
A

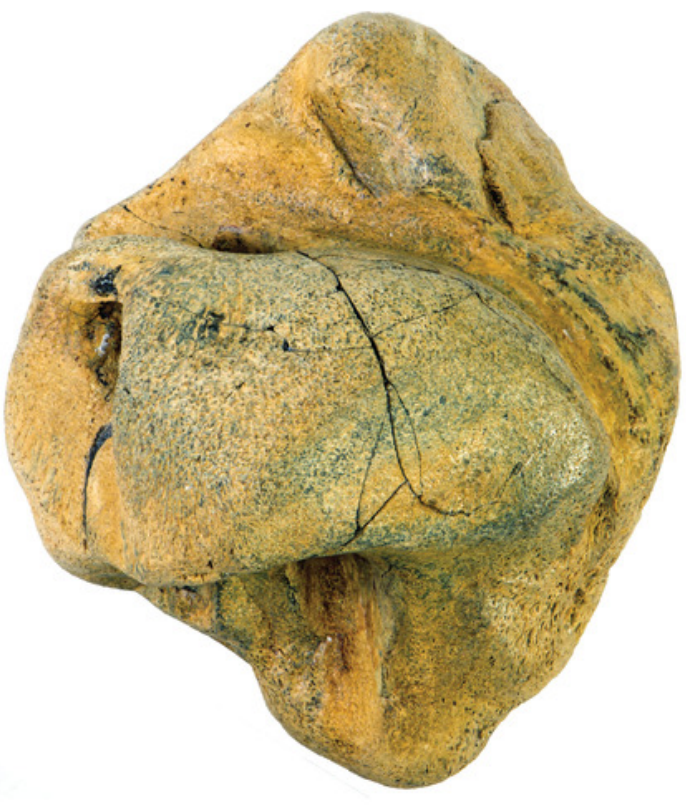

C
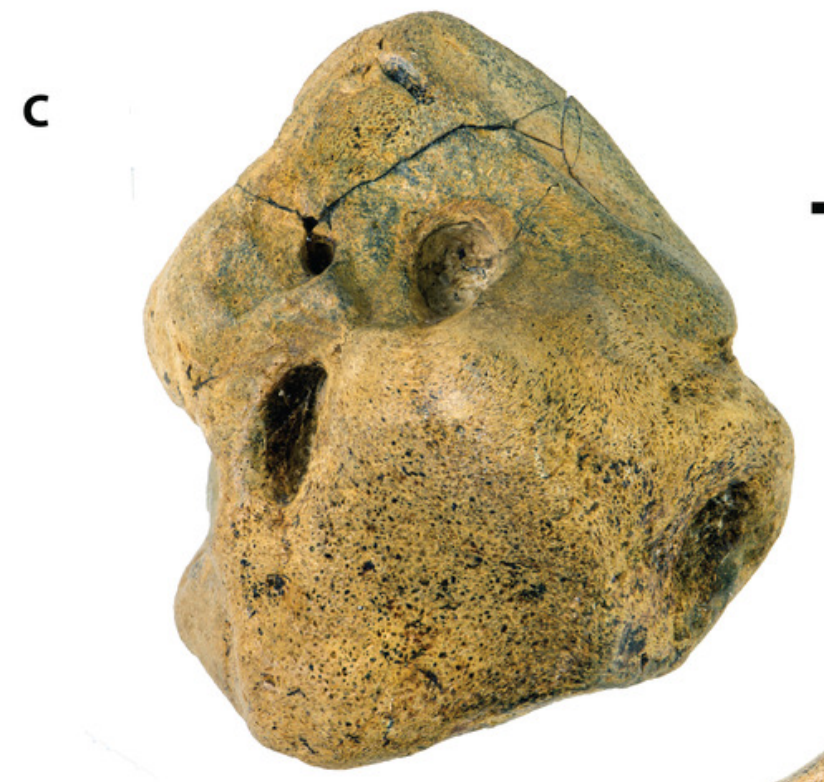

B

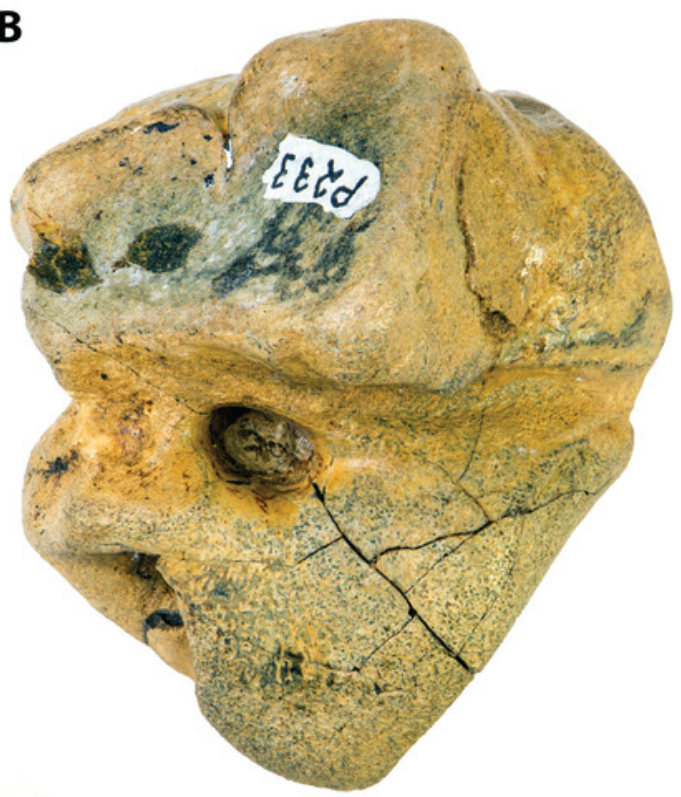

$\mathbf{E}$

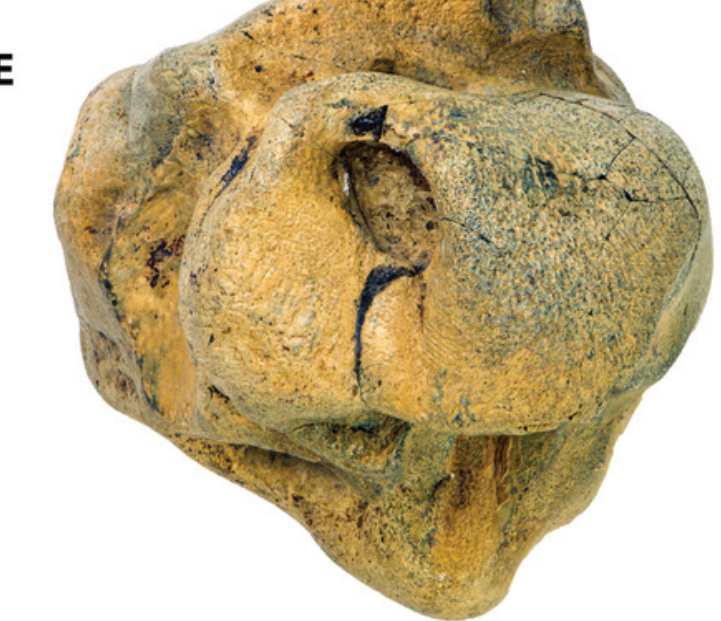


Figure 2

Caperea sp. (NMV P233333), right periotic - explanatory line drawings.

Photo credit: Felix G. Marx. 

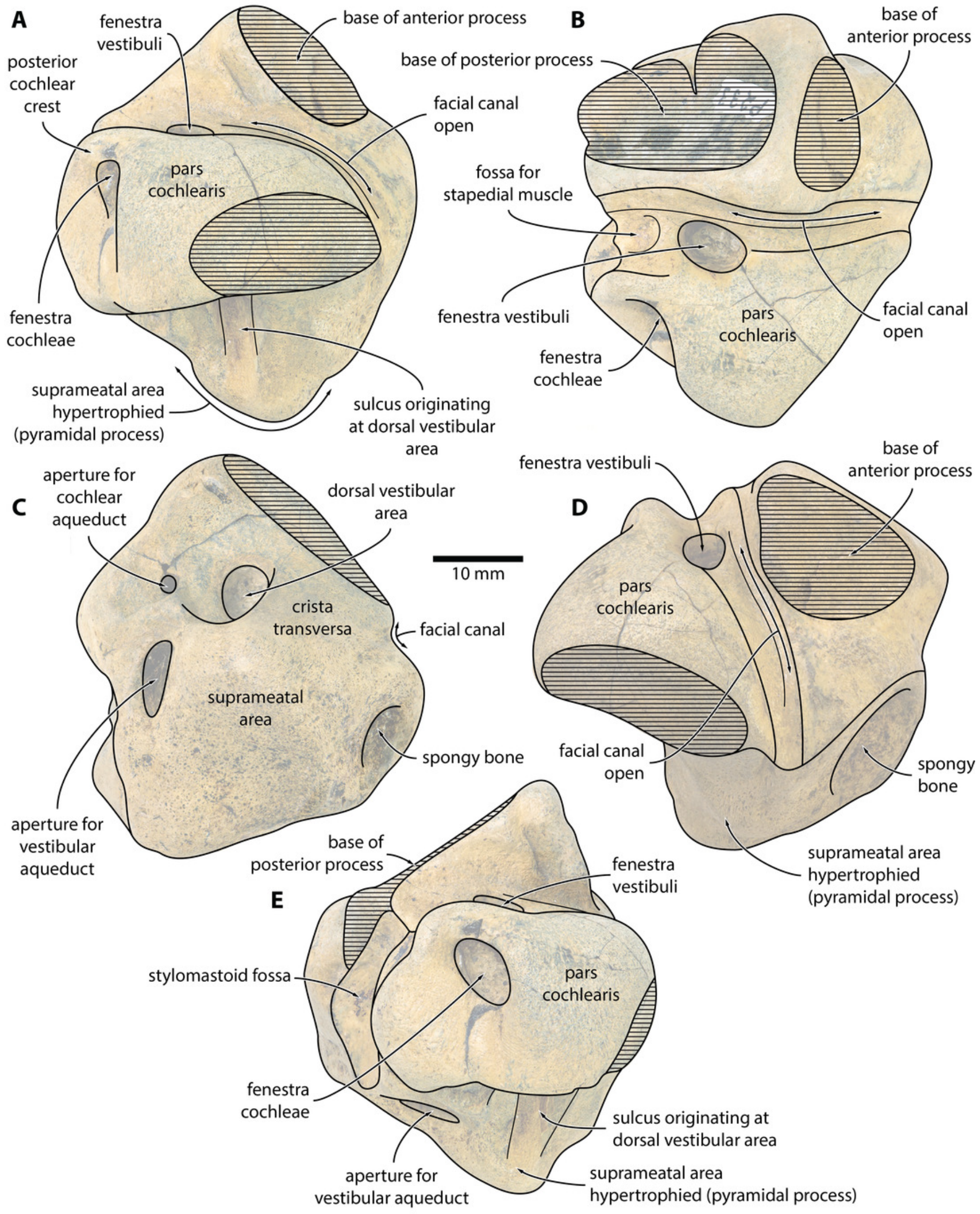
Figure 3

Inner ear of Caperea sp. (NMV P233333).

Digital model reconstructed from microCT data in (A) anterior, (B) lateral, (C) dorsal and (D) vestibular view. 

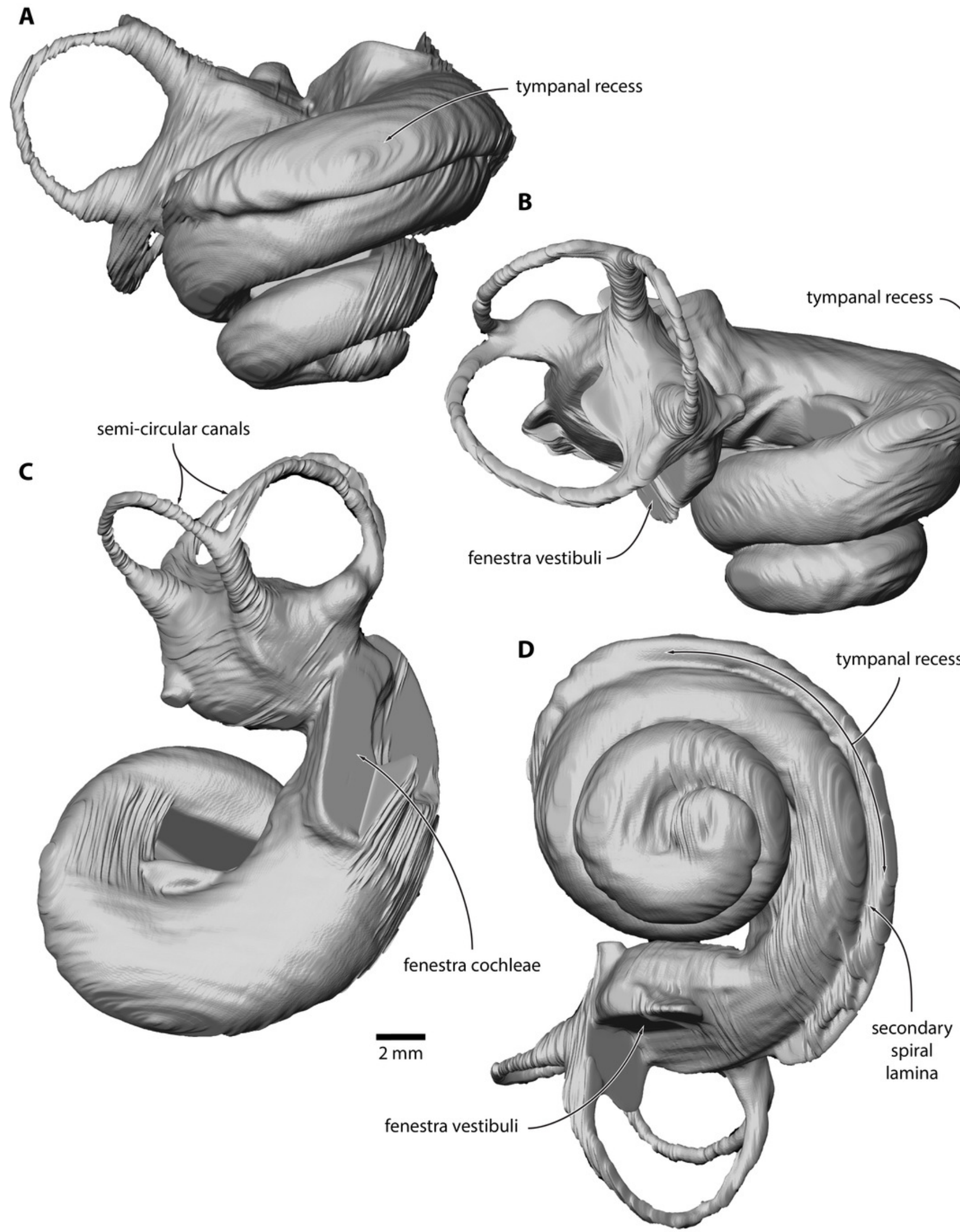
Figure 4

Comparison of Caperea sp. with extant C. marginata.

(A, D) Caperea sp. (NMV P233333) and (B, C) extant C. marginata (NMV C28531) in (A, B) ventral and (C, D) posterior view. Photo credit: Felix G. Marx. 
neck of anterior process
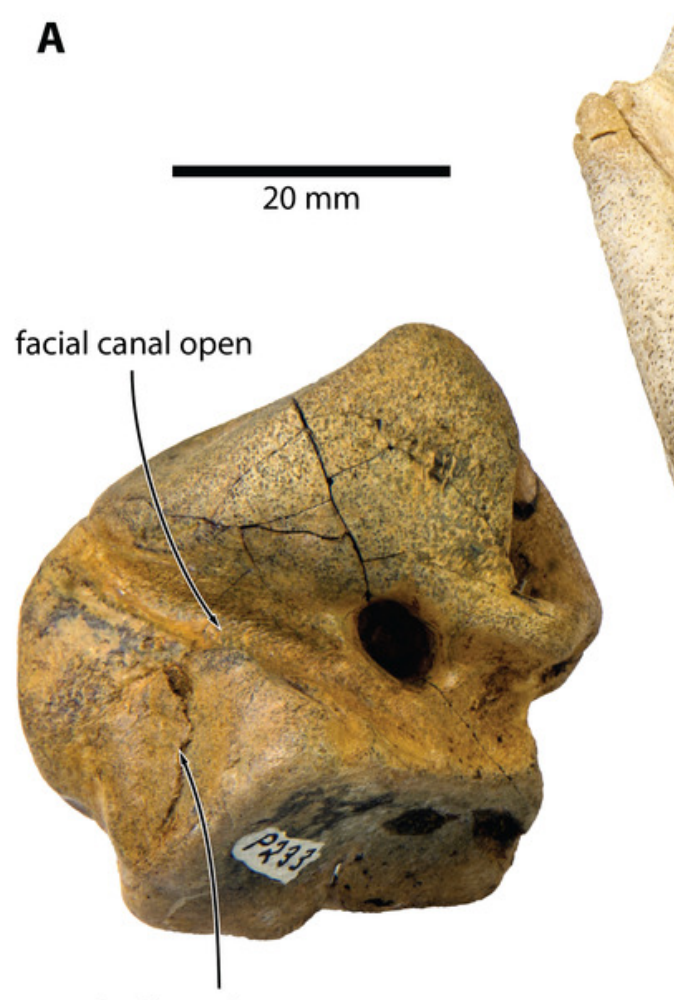

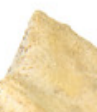

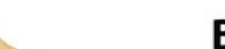

B

facial canal open large fenestra vestibuli

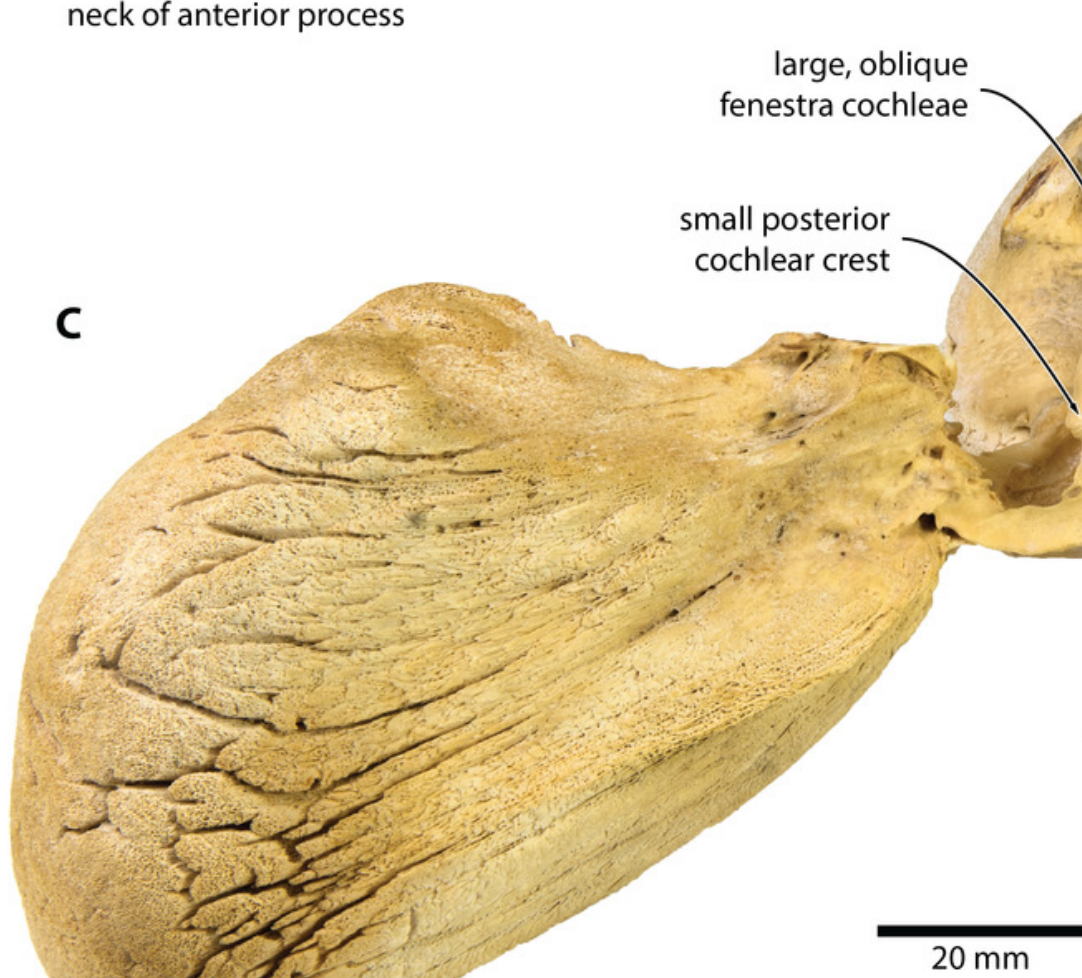
small posterior cochlear crest fenestra cochleae 


\section{Figure 5}

Comparison of Caperea sp. with extant C. marginata.

(A) Caperea marginata (NMV C28531) and (B) Caperea sp. (NMV P233333), both in dorsal view. Photo credit: Felix G. Marx.

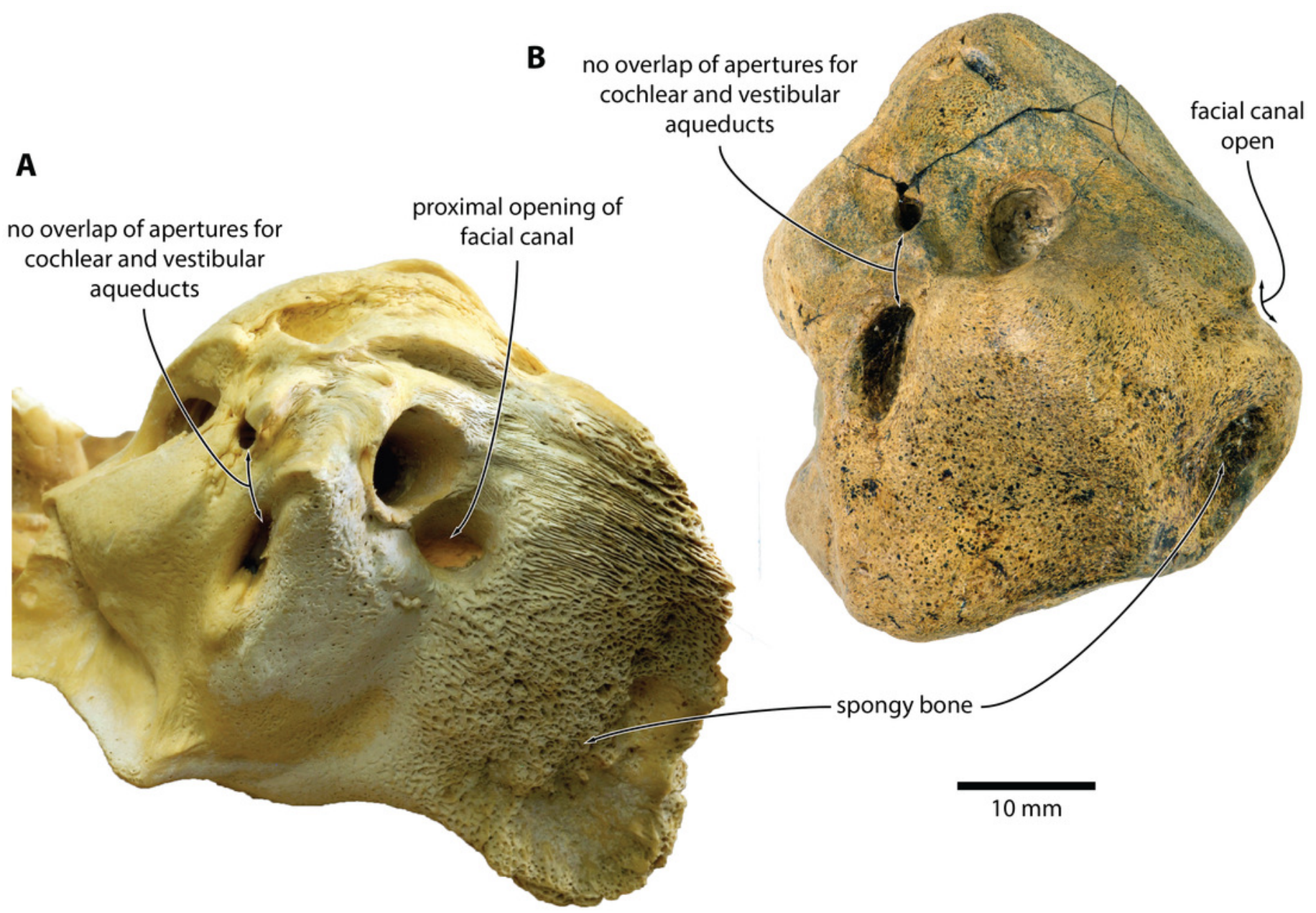




\section{Figure 6}

Global occurrence and age of neobalaenine fossils.

(A) Map illustrating neobalaenine fossil localities, as well as the geographical distribution of extant Caperea marginata. (B) Simplified phylogeny showing the fossil record of the three major lineages of extant baleen whales. For neobalaenines, dark green and red denote Southern and Northern Hemisphere occurrences, respectively. Grey illustrates the total cetotheriid fossil record. The age of NMV P233333 is marked with an asterisk. (A) modified from Tsai et al. (2017), (B) from Fitzgerald (2012) and Buono et al. (2014), under a Creative Commons Attribution License. Drawings of extant whales by Carl Buell. L., Late; Pleist., Pleistocene; Plio., Pliocene; Qu., Quaternary. 

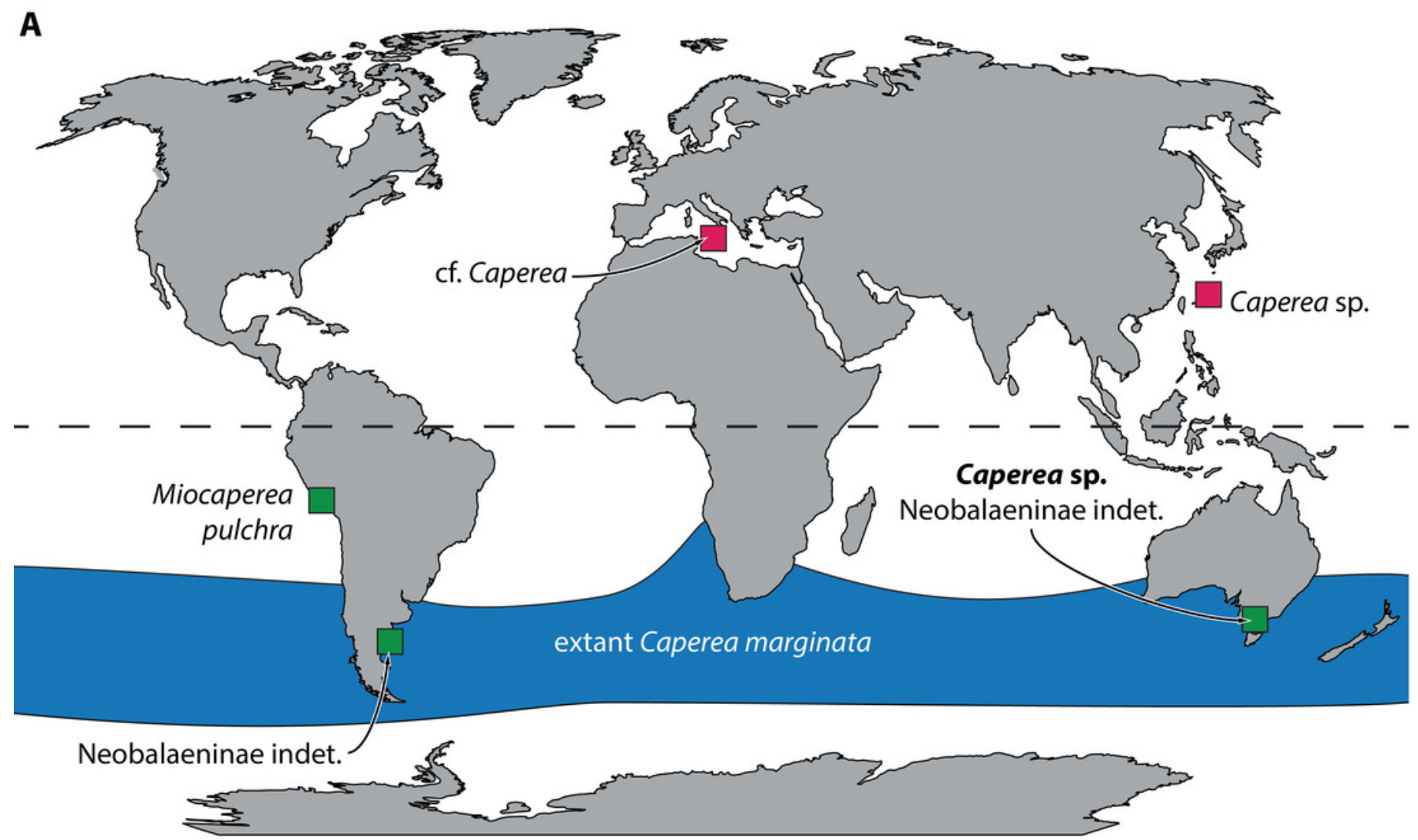

B

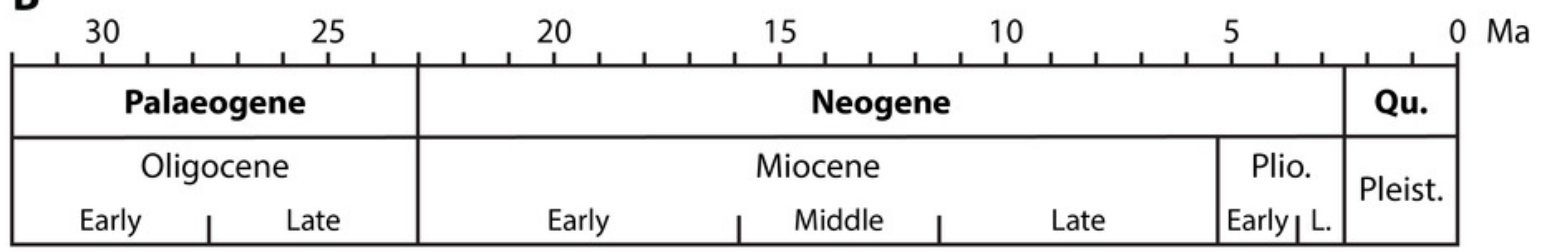

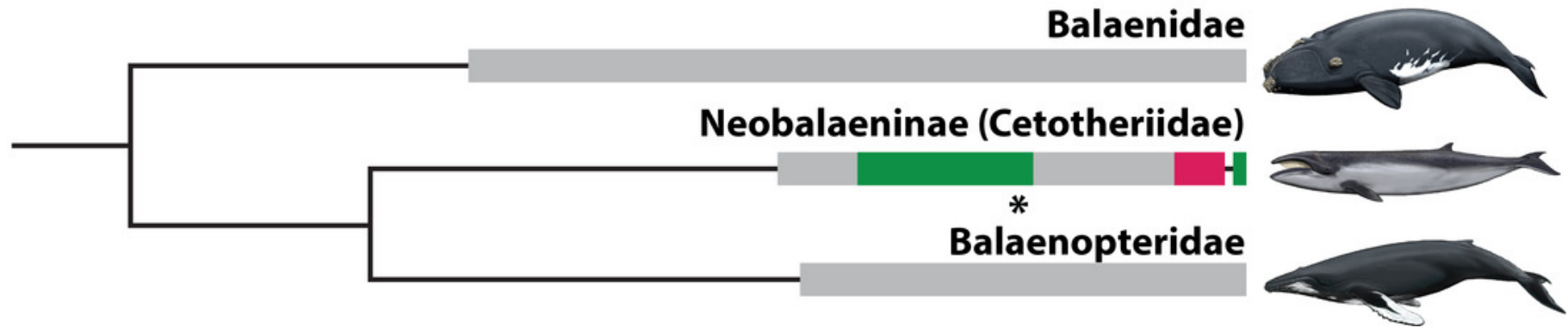

